\title{
Anthropometric evaluation of indigenous Brazilian children under 60 months of age using NCHS/1977 and WHO/2005 growth curves
}

\author{
Jesem D. Y. Orellana, ${ }^{1}$ Ricardo V. Santos², Carlos E. A. Coimbra Jr., ${ }^{3}$ \\ Maurício S. Leite ${ }^{4}$
}

\begin{abstract}
Objectives: To perform a comparative analysis of anthropometric data from Suruí, Xavánte and Wari' indigenous children under 60 months of age using the NCHS/1977 and the WHO/2005 growth curves.

Methods: Anthropometric measurements followed standard procedures and the data obtained were converted into $z$ scores using the Epi-Info (Version 3.4) and WHO-Anthro (Version Beta) softwares. The indices height/age (H/A), weight/age (W/A) and weight/height $(\mathrm{W} / \mathrm{H})$ were descriptors of nutritional status for all children under 60 months of age, as well as the body mass index (BMI) for children 24-59 months old.

Results: The frequencies of Suruí children <-2 z scores for H/A were 31.4 (NCHS/1977) and 38.6\% (WHO/2005); Xavánte 30.9 and $42.3 \%$; Wari' 61.7 and $68.3 \%$. The frequencies of Suruí children < -2 z scores for W/A were 12.4 (NCHS/1977) and 8.5\% (WHO/2005); Xavánte 16.5 and 11.6\%; Wari' 51.7 and $45.0 \%$. None of the Suruí children were < - 2 z scores for W/H (NCHS/1977 and WHO/2005); the frequencies of Xavánte children were 1.7 and $3.3 \%$ and Wari' 1.7 and $0.0 \%$. The frequencies of Suruí children > 2 z scores for W/H were 3.9 (NCHS/1977) and 3.9\% (WHO/ 2005); Xavánte 0.0 and $0.8 \%$; Wari' 0.0 and $0.0 \%$. The frequency of Suruí children aged $24-59$ months $>2$ z scores for BMI was 5.4\% (WHO/2005); Xavánte 9.5\%; and Wari' $0.0 \%$.

Conclusions: Our findings revealed important differences in the results from nutritional assessment, according to the set of growth curves used; however, the use of both growth curves revealed a high prevalence of malnutrition. Therefore, future studies with indigenous populations should present their results using two sets of growth curves to allow consistent comparison.
\end{abstract}

J Pediatr (Rio J). 2009;85(2):117-121: Anthropometry, nutritional assessment, growth curves, South American Indians.

\section{Introduction}

Malnutrition is one of the main components of the morbidity and mortality profile of indigenous children in Brazil. ${ }^{1,2}$ The indigenous population in the country is quite diverse, though studies including this diversity are currently lacking. Nevertheless, studies indicate high prevalence of nutritional disorders in children under 60 months of age, which, overall, is much higher than the Brazilian means. ${ }^{2}$

1. Mestre. Pesquisador assistente, Instituto Leônidas e Maria Deane, Fundação Oswaldo Cruz (FIOCRUZ), Manaus, AM, Brazil.

2. Doutor. Pesquisador titular, Escola Nacional de Saúde Pública Sergio Arouca, FIOCRUZ, Rio de Janeiro, RJ, Brazil. Pesquisador adjunto, Departamento de Antropologia, Museu Nacional, Universidade Federal do Rio de Janeiro (UFRJ), Rio de Janeiro, RJ, Brazil.

3. Doutor. Pesquisador titular, Escola Nacional de Saúde Pública Sergio Arouca, FIOCRUZ, Rio de Janeiro, RJ, Brazil.

4. Doutor. Pesquisador adjunto, Departamento de Nutrição, Centro de Ciências da Saúde, Universidade Federal de Santa Catarina (UFSC), Florianópolis, SC, Brazil.

Financial support: Conselho Nacional de Desenvolvimento Científico e Tecnológico (CNPq; protocols no. 141242/2000-0, 506392/2004-0 and 470850/2004-3), Coordenação de Aperfeiçoamento de Pessoal de Nível Superior (CAPES), Programa de Apoio à Pesquisa Estratégica em Saúde (Fundação Oswaldo Cruz), and Fundação Ford.

No conflicts of interest declared concerning the publication of this article.

Suggested citation: Orellana JD, Santos RV, Coimbra Jr. CE, Leite MS. Anthropometric evaluation of indigenous Brazilian children under 60 months of age using NCHS/1977 and WHO/2005 growth curves. J Pediatr (Rio J). 2009;85(2):117-121.

Manuscript received Aug 13 2008, accepted for publication Dec 222008.

doi:10.2223/JPED.1872 
The assessment of nutritional status by anthropometry is an important tool in the analysis of health and nutritional condition of children. Over the last three decades, in the international scenario, two sets of physical growth curves have been predominantly used: those from the National Center for Health Statistics (NCHS/1977) $)^{3,4}$ and from the Centers for Disease Control (CDC/2000), ${ }^{5}$ both based on the North American population. During this period, with rare exceptions, studies on anthropometric evaluation of Brazilian children, including indigenous children, have used the NCHS/1977 reference. $^{3}$

Despite the critical considerations about both the NCHS/ $1977^{3,6}$ and the CDC/2000 references, ${ }^{7,8}$ only in 2006 the World Health Organization (WHO) published their own set of growth curves (herein indicated as WHO/2005) to assess nutritional status of children under 60 months of age. ${ }^{9}$ The WHO/2005 resulted from a multicenter study carried out in four continents. This new set of growth curves is likely to replace those previously used in the assessment of nutritional status. This is the case of Brazil, where the WHO/2005 is already recommended by the Brazilian Ministry of Health. Worth mentioning that there are studies comparing the frequencies of nutritional disorders from the NCHS/1977 and the WHO/2005 set of growth curves, ${ }^{10,11}$ which call attention not only to the differences in estimates of child nutritional status and to the practical implications of adopting the WHO/2005 new set of curves in health care service, but also to the fact that healthy children, living in healthy environments and whose eating habits are considered excellent during childhood, tend to show a similar profile of growth and development in both sets of curves.

The objective of this study is to perform a comparative analysis of the frequencies of nutritional disorders in children under 60 months of age from three indigenous ethnic groups of the Brazilian Amazon region using the NCHS/1977 and the WHO/2005 sets of growth curves.

\section{Methods}

Anthropometric data were obtained from children under 60 months of age of three indigenous populations of the Brazilian Amazon: 153 Suruí children (data collected in 2005) and 60 Wari' children (data collected in 2003), both located in the state of Rondônia; and 123 Xavánte children from the state of Mato Grosso (data collected in 1996). Measurements of length/height and body mass (herein referred as weight) were performed according to the methodology recommended by the WHO. ${ }^{6}$ Children aged more than 23 months had their height measured in the orthostatic position, whereas the younger children had their length measured in the dorsal position, using a portable anthropometer with precision to $0.1 \mathrm{~cm}$. Weight was measured using an electronic digital scale, with maximum capacity of $150 \mathrm{~kg}$ and precision to $0.1 \mathrm{~kg}$. For the younger children, mothers holding their babies were weighted; the adult's weight was then subtracted to obtain the child's measurement.

This study is based on reanalyses of data previously worked. Methodological procedures, individual characteristics of the samples, as well as their respective analyses, were presented in Orellana et al., ${ }^{12}$ Leite et al., ${ }^{13}$ and Leite et al. ${ }^{14}$ The samples include at least $80 \%$ of children at the considered age group of each one of the populations. The three studies followed the recommendations by the $\mathrm{WHO}^{6}$ for data collection.

Conversion of anthropometric values (height and weight) to $z$ scores was performed using the Epi-Info version 3.4 (CDC, Atlanta, Georgia, USA) and WHO-Anthro version Beta (WHO, Department of Nutrition, Geneva, Switzerland). The sets of growth curves used in this study were the NCHS/1077 and the WHO/2005. The height/age (H/A), weight/age (W/A), weight/height $(\mathrm{W} / \mathrm{H})$ indices and the body mass index (BMI) for age were descriptors of nutritional status. $Z$ score values $<-2$ for the $\mathrm{H} / \mathrm{A}, \mathrm{W} / \mathrm{A}$ and $\mathrm{W} / \mathrm{H}$ indices were used to characterize short stature for age, low weight for age and low weight for height, respectively. $Z$ score values $>2$ for the $\mathrm{W} / \mathrm{H}$ index were considered indicative of overweight status. Statistical analysis was performed using the SPSS version 9.0 software (SPSS Inc., Chicago IL, USA). The Student $t$ test and chi-square $\left(X^{2}\right)$ test were used for data analysis. The level of significance was set at $p<0.05$.

The research carried out where the anthropometric data herein analyzed were collected was approved by the Research Ethics Committee of the Escola Nacional de Saúde Pública Sergio Arouca (ENSP/FIOCRUZ), Brazil, according to Orellana et al., ${ }^{12}$ Leite et al. ${ }^{13}$ and Leite et al. ${ }^{14}$

\section{Results}

None of the three samples showed any significant differences regarding the proportion of boys and girls $(p>0.05)$ or regarding the mean age between sexes $(p>0.05)$. There were no significant differences in the proportion of nutritional disorders between sexes ( $p>0.05)$.

Important differences were observed between the values generated by the sets of growth curves, according to the H/A index (Table 1). In the contrast of the proportions of short stature for age, in the sample of children under 60 months of age, we observed that the use of the WHO/2005 implied a mean increase of $23.6 \%$ in prevalence in relation to the $\mathrm{NCHS/}$ 1077 , with a variation of 31.4 to $38.6 \%$ in the Suruí group, 30.9 to $42.3 \%$ in the Xavánte group, and 61.7 to $68.3 \%$ in the Wari' group. The W/A index variation occurred in the opposite direction (-29.5\%), decreasing from 12.4 to $8.5 \%$ of low weight for age in the Suruí group, from 16.5 to $11.6 \%$ in the Xavánte group, and from 51.7 to $45.0 \%$ in the Wari' group. Prevalence of low weight for height was reduced from both sets of growth curves. In this case, the variations were mainly due to fluctuations in small numbers. In the three samples, 
Table 1 - Distribution of combined prevalence and percentage variations of indigenous children under 60 months of age with $z$ scores $<-2$ for height/age (H/A), weight/age (W/A) and weight/height $(\mathrm{W} / \mathrm{H})$ indices, according to sets of anthropometric growth curves and age group (Rondônia, 2003 and 2005; Mato Grosso, 1996)

\begin{tabular}{|c|c|c|c|c|c|c|c|c|c|}
\hline \multirow[b]{2}{*}{$\begin{array}{l}\text { Age } \\
\text { group } \\
\text { (months) }\end{array}$} & \multicolumn{3}{|c|}{ H/A } & \multicolumn{3}{|c|}{ W/A } & \multicolumn{3}{|c|}{$\mathbf{W} / \mathbf{H}$} \\
\hline & $\begin{array}{c}\text { NCHS/ } \\
1977 \\
\% \text { (n) }\end{array}$ & $\begin{array}{c}\text { WHO/ } \\
2005 \\
\%(n)\end{array}$ & $\begin{array}{c}\text { Variation } \\
\%\end{array}$ & $\begin{array}{c}\text { NCHS/ } \\
1977 \\
\% \text { (n) }\end{array}$ & $\begin{array}{c}\text { WHO/ } \\
2005 \\
\% \text { (n) }\end{array}$ & $\begin{array}{c}\text { Variation } \\
\%\end{array}$ & $\begin{array}{c}\text { NCHS/ } \\
1977 \\
\%(n)\end{array}$ & $\begin{array}{c}\text { WHO/ } \\
2005 \\
\%(n)\end{array}$ & $\begin{array}{c}\text { Variation } \\
\%\end{array}$ \\
\hline \multicolumn{10}{|l|}{ Suruí } \\
\hline 24 to 35 & $37.1(35)$ & $54.3(35)$ & $+46.4 \%$ & $22.9(35)$ & $11.4(35)$ & $-100.9 \%$ & $-(35)$ & $-(35)$ & - \\
\hline 36 to 59 & $39.7(58)$ & $44.8(58)$ & $+12.8 \%$ & $15.5(58)$ & $10.3(58)$ & $-50.5 \%$ & $-(58)$ & $-(58)$ & - \\
\hline 0 to 59 & $31.4(153)$ & $38.6(153)$ & $+22.9 \%$ & $12.4(153)$ & $8.5(153)$ & $-45.9 \%$ & $-(153)$ & $-(153)$ & - \\
\hline \multicolumn{10}{|l|}{ Xavánte } \\
\hline 0 to 23 & $29.2(48)$ & $31.3(48)$ & $+7.2 \%$ & $29.8(47)$ & $21.3(47)$ & $-39.9 \%$ & $4.3(46)$ & $8.7(46)$ & $+102.3 \%$ \\
\hline 24 to 35 & $29.6(27)$ & $51.9(27)$ & $+75.3 \%$ & $7.7(26)$ & $-(26)$ & $-100.0 \%$ & $-(26)$ & $-(26)$ & - \\
\hline 36 to 59 & $33.3(48)$ & $47.9(48)$ & $+43.8 \%$ & $8.3(48)$ & $8.3(48)$ & - & $-(48)$ & $-(48)$ & - \\
\hline 0 to 59 & 30.9 (123) & $42.3(123)$ & $+36.9 \%$ & $16.5(121)$ & $11.6(121)$ & $-42.2 \%$ & $1.7(120)$ & $3.3(120)$ & $+94.1 \%$ \\
\hline \multicolumn{10}{|l|}{ Wari' } \\
\hline 0 to 23 & $56.0(25)$ & $64.0(25)$ & $+14.3 \%$ & $40.0(25)$ & $36.0(25)$ & $-11.1 \%$ & $4.0(25)$ & $-(25)$ & $-100.0 \%$ \\
\hline 24 to 35 & $54.5(11)$ & $72.7(11)$ & $+3.4 \%$ & $63.6(11)$ & $54.5(11)$ & $-16.7 \%$ & - (11) & $-(11)$ & - \\
\hline 36 to 59 & $70.8(24)$ & $70.8(24)$ & - & $58.3(24)$ & $50.0(24)$ & $-16.6 \%$ & $1.7(24)$ & $-(24)$ & $-100.0 \%$ \\
\hline 0 to 59 & $61.7(60)$ & $68.3(60)$ & $+10.7 \%$ & $51.7(60)$ & $45.0(60)$ & $-14.9 \%$ & $1.7(60)$ & $-(60)$ & $-100.0 \%$ \\
\hline \multicolumn{10}{|l|}{ Total } \\
\hline 0 to 23 & $29.6(133)$ & $33.8(133)$ & $+14.1 \%$ & $19.7(132)$ & $16.7(132)$ & $-18.1 \%$ & $2.3(131)$ & $3.1(131)$ & $+34.4 \%$ \\
\hline 24 to 35 & $36.9(73)$ & $56.2(73)$ & $+52.1 \%$ & $23.6(72)$ & $13.9(72)$ & $-70.4 \%$ & $-(72)$ & $-(72)$ & - \\
\hline 36 to 59 & $43.1(130)$ & $50.7(130)$ & $+17.8 \%$ & $20.7(130)$ & $16.9(130)$ & $-22.8 \%$ & $0.3(130)$ & $-(130)$ & $-100 \%$ \\
\hline
\end{tabular}

$\mathrm{H} / \mathrm{A}=$ height/age index; NCHS = National Center for Health Statistics; W/A = weight/age index; W/H = weight/height index; WHO = World Health Organization.

the most expressive variations, when comparing the results from both curves, occurred in the 24 to 35-month age group. Variations in the other two age groups ( 0 to 23 and 36 to 59 months) were less expressive.

Regarding overweight status, frequencies were the same (3.9\%) among Suruí children from both sets of growth curves. Among Xavánte children, the WHO/2005 resulted in the identification of only one case of overweight $(0.8 \%)$, which was not detected by the NCHS/1077. Among Wari' children, no cases of overweight were detected, regardless of the set of growth curves being used. Between Suruí and Xavánte children, 24 to 59 months of age, overweight, according to the BMI-WHO/2005, was 5.4 and 9.5\%, respectively. In Wari' children, no cases of overweight were detected.

\section{Discussion}

Regardless of the set of curves used to describe the nutritional status of Suruí, Xavánte and Wari' children, as stated by previous studies, ${ }^{12-14}$ the analyses indicate high prevalence of malnutrition. These results, when compared to those from the recent Brazilian Woman and Child Health and Demographic Research (Pesquisa Nacional de Demografia e Saúde da Criança e da Mulher), ${ }^{15}$ which also used the new WHO curves, ${ }^{9}$ revealed important differences. Particularly, we highlight the magnitude of short stature for age, approximately six-fold higher in indigenous children when compared to non-indigenous children. We can state that our findings are in accordance with the respective health profiles of the indigenous populations under study, marked by high infant mortality and morbidity rates resulting from infectious and parasitic diseases. ${ }^{12-14,16}$

Important differences were observed between the frequencies of nutritional descriptors generated by the two sets of growth curves, with variations dependent on population, age group and anthropometric index. In general, variations in prevalence followed the trend of increase in short stature for age and decrease in low weight for age when the WHO/ 2005 was used, in accordance with the results from other studies with non-indigenous samples. ${ }^{10,11}$ An expressive part of these variations may be explained by the individual characteristics of each one of the curves, such as feeding inclusion criteria (e.g. exclusively or predominantly breastfed 
infants, for at least 4 months, in the WHO/2005 sample vs. predominantly formula-fed infants in the NCHS/1977), sample composition (multicenter study in the case of the WHO/2005, which was based on a sample of children from four continents; in the case of the NCHS/1977, only North American children) and different data collection time intervals (between 1929 and 1975 for the NCHS/1977; and between 1997 and 2003 for the WHO/2005). 6,11,17

Overall, regardless of the curve used, prevalence of low weight for height was low or null, maintaining the body proportionality among the indigenous children under study. Some authors have already linked these results to a greater concentration of body water associated to malnutrition ${ }^{18}$ and/or a greater chest-head proportion. ${ }^{19}$ Onis et al. ${ }^{11}$ suggest that prevalence of low weight for height, mainly at the first years of life, is higher when the WHO/2005 is used, compared to the prevalence using the NCHS/1977. This was the case of the Xavánte children, but not of the Suruí and Wari'. However, the reduced number of children under 60 months of age in the three ethnic groups, mainly among the Wari', as well as the methodological limitations of prevalence studies, which basically work with survivors and individuals present in the moment of data collection, may have affected the results.

In the indigenous children, there were few cases of overweight status from the $\mathrm{W} / \mathrm{H}$ index. The BMI for age, on the other hand, showed greater sensitivity, resulting in important changes in the prevalence of overweight among and within the ethnic groups. Although studies with empirical data from the WHO/2005 set of growth curves are not available, which could establish risk models associating child overweight with subsequent obesity or other diseases, the increase in estimates of overweight generated by the BMI in relation to those obtained from the $\mathrm{W} / \mathrm{H}$ index for both curves deserves attention. It is worth mentioning that the data on overweight indicate two very distinct situations, which continue in the adolescent and adult profiles of these same ethnic groups. Among the Wari', overweight and obesity are rare occurrences, whereas among the Suruí and the Xavánte prevalence reaches alarming rates. ${ }^{13,16,20}$

If for Brazilian children there are several national studies which allow characterizing the malnutrition trajectory, such as the Brazilian Study on Family Expenses (Estudo Nacional da Despesa Familiar, ENDEF), the Brazilian Health and Nutrition Survey (Pesquisa Nacional sobre Saúde e Nutrição, PNSN), the Brazilian Demographic and Health Policy (Política Nacional de Demografia e Saúde, PNDS), the Brazilian Family Expenditure Survey (Pesquisa de Orçamentos Familiares, POF), among others, ${ }^{21}$ for indigenous children what is known about the nutritional status results from case studies of specific ethnic groups. ${ }^{1,2}$ For the several national surveys, which present a consolidated database, it is feasible to perform reananlyses from the new set of growth curves, giving rise to comparable results. In the case of indigenous children, databases are scattered, usually belonging to the researchers who carried out the study. Thus, with the adoption of the WHO/ 2005 , we may miss comparability with previous studies about nutritional status of indigenous children, which in most part are based on the NCHS/1977. This is a serious problem, since monitoring the nutritional status of indigenous children is of paramount importance, considering, in particular, the vulnerability that these populations, in accelerated processes of socioeconomic and environmental changes, present regarding the nutritional dimension. ${ }^{2}$

In view of the foregoing, investigations with indigenous populations in Brazil, which are still initial and outlining a broader epidemiologic picture, should show their results using not only the most recent set of growth curves (WHO/2005), but also previous curves, particularly the $\mathrm{NCHS} / 1977$, in order to allow comparability over time.

\section{Acknowledgements}

We are grateful to the support provided by the Brazilian National Council for Research and Development (Conselho Nacional de Desenvolvimento Científico e Tecnológico, CNPq; protocols no. $141242 / 2000-0,506392 / 2004-0$ and 470850 / 2004-3), the Coordination for the Improvement of Higher Education Personnel (Coordenação de Aperfeiçoamento de Pessoal de Nível Superior, CAPES), the Strategic Health Research Program (Programa de Apoio à Pesquisa Estratégica em Saúde), by Fundação Oswaldo Cruz, and Ford Foundation, for the financial support.

\section{References}

1. Santos RV, Coimbra Jr CE. Cenários e tendências da saúde e da epidemiologia dos povos indígenas no Brasil. In: Coimbra $C E$, Santos RV, Escobar AL, organizadores. Epidemiologia e saúde dos povos indígenas no Brasil. Rio de Janeiro: Fiocruz; 2003. p. 13-47.

2. Leite MS, Santos RV, Coimbra Jr CE, Gugelmin AS. Alimentação e nutrição dos povos indígenas no Brasil. In: Kac G, Sichieri R. Gigante DP, organizadores. Epidemiologia Nutricional. Rio de Janeiro: Fiocruz/Atheneu; 2007. p. 503-17.

3. Hamill PV, Drizd TA, Johnson CL, Reed RB, Roche A, Moore WM. Physical growth: National Center for Health Statistics percentiles. Am J Clin Nutr. 1979;32:607-29.

4. Dibley MJ, Goldsby JB, Staehling NW, Trowbridge FL. Development of normalized curves for the international growth reference: historical and technical considerations. Am J Clin Nutr. 1987; 46:736-48.

5. Kuczmarski RJ, Ogden CL, Guo SS, Grummer-Strawn LM, Flegal KM, Mei Z, et al. CDC growth charts: United States. Advance data from vital and health statistics; no. 314. Hyattsville, MD: National Center for Health Statistics; 2000.

6. World Health Organization Working Group on Infant Growth. An evaluation of infant growth: the use and interpretation of anthropometry in infants. Bull World Health Organ. 1995;73: 165-74. 
7. de Onis M, Onyango AW. The Centers for Disease Control and Prevention 2000 growth charts and the growth of breastfed infants. Acta Paediatr. 2003;92:413-9.

8. de Onis M, Garza C, Onyango AW, Borghi E. Comparison of the WHO Child Growth Standards and the CDC 2000 Growth Charts. J Nutr. 2007;137:144-8

9. World Health Organization. WHO Child Growth Standards: length/height-for-age, weight-for-age, weight-for-length, weight-for-height and body mass index-for-age. Methods and development. WHO (nonserial publication). Geneva: WHO; 2006.

10. Seal A, Kerac M. Operational implications of using 2006 World Health Organization growth standards in nutrition programmes: secondary data analysis. BMJ. 2007;334:733.

11. de Onis M, Onyango AW, Borghi E, Garza C, Yang H; WHO Multicentre Growth Reference Study Group. Comparison of the World Health Organization (WHO) Child Growth Standards and the National Center for Health Statistics/WHO international growth reference: implications for child health programmes. Public Health Nutr. 2006;9:942-7.

12. Orellana JD, Coimbra Jr CE, Lourenço AE, Santos RV. Nutritional status and anemia in Suruí Indian children, Brazilian Amazon. J Pediatr (Rio J). 2006;82:383-8.

13. Leite MS, Santos RV, Gugelmim SA, Coimbra Jr CE. [Physical growth and nutritional profile of the Xavánte indigenous population in Sangradouro-Volta Grande, Mato Grosso, Brazil]. Cad Saude Publica. 2006;22:265-76.

14. Leite MS, Santos RV, Coimbra Jr CE. [Seasonality and nutritional status of indigenous peoples: the case of Wari' in Rondônia State, Brazil]. Cad Saude Publica. 2007;23:2631-42.

15. Brasil. Ministério da Saúde. PNDS - 2006: Pesquisa Nacional de Demografia e Saúde da Criança e da Mulher. Relatório (Versão preliminar). Brasília: Ministério da Saúde; 2008.
16. Orellana JD, Basta PC, Santos RV, Coimbra Jr CE. Morbidade hospitalar em crianças indígenas Suruí menores de dez anos, Rondônia, Brasil: 2000 a 2004. Rev Bras Saude Mater Infant. 2007;7:281-7.

17. WHO Multicentre Growth Reference Study Group. WHO child growth standards based on length/height, weight and age. Acta Paediatr Suppl. 2006;450:76-85.

18. Trowbridge FL, Marks JS, Lopez de Romana G, Madrid S, Boutton TW, Klein PD. Body composition of Peruvian children with short stature and high weight-for-height. II. Implications for the interpretation for weight-for-height as an indicator of nutritional staus. Am J Clin Nutr. 1987;46:411-8.

19. Post CL, Victora CG, Barros A]. [Low prevalence of bodyweight-for-height deficit: comparison of stunned and no-stunned Brazilian children]. Rev Saude Publica. 1999;33: 575-85.

20. Lourenço $A E$, Santos RV, Orellana JD, Coimbra Jr CE. Nutrition transition in Amazonia: obesity and socioeconomic change in the Suruí Indians from Brazil. Am J Hum Biol. 2008;20:564-71.

21. Conde WL, Gigante DP. Epidemiologia da desnutrição infantil. In: Kac G, Sichieri R, Gigante DP, organizadores. Epidemiologia nutricional. Rio de Janeiro, RJ: Fiocruz/Atheneu; 2007. p.281-95.

Correspondence:

Jesem D. Y. Orellana

Instituto Leônidas e Maria Deane

Fundação Oswaldo Cruz

Rua Teresina, 476

CEP 69057-070 - Manaus, AM - Brazil

E-mail: jesem_orellana@amazonia.fiocruz.br 